\title{
臨床評価における統計学上の論点: 欠測値の諸問題 Points to Consider on Missing Data
}

\author{
渡辺秀章 * • 田崎武信 $*$ \\ Hideaki Watanabe and Takenobu Tasaki \\ *塩野義製薬 (株) 医薬研究開発本部 解析センター \\ Biostatistics Dept., SHIONOGI \& CO., LTD \\ e-mail: hideaki.watanabe@shionogi.co.jp
}

\begin{abstract}
In clinical trials, missing data often happens for a variety of reasons, such as dropouts, making it difficult to analyze the primary variable measured longitudinally and to interpret the results of the primary analysis. While handling missing data sometimes causes bias in the results, there have been no established statistical approaches applied to missing data in appropriate situations. In November 2001, Committee for Proprietary Medical Product of the European Medicines Agency, issued "Points to Consider (PtC) on Missing Data", which focuses on several points that should be taken into account when handling missing data in clinical trials. In this paper, we review the contents of this $\mathrm{PtC}$, which assumes that the primary analysis is based on the ITT principle, and discuss some of the approaches for handling missing data and the difficulties in interpreting these results.
\end{abstract}

Key words: Clinical trial, Longitudinal data, Missing data, Drop-out, LOCF, Imputation.

1.はじめに

臨床試験では，有効性を評価するための主要変数が実施計画書で規定された時点上で観測され， 事前に規定された投与期間における推移パターンあるいは投与期間の最終時点の観測值に基づい て試験薬の薬効か評価されることが多い．しかしながら，所与の観測時点に来院せずに光の時点 で欠測，あるいは，種々の理由から試験から脱落し，光の時点以降が欠測となることが少なくな い. 比較臨床試験では, ITT の原則から割付けられたすべての症例を解析対象集団に含めて解析 を行うことが必要になるため, 主要変数に関して欠測値を含む症例も何らかの形で解析上のとり 扱いを決めた上で主要解析に含める必要性が生じる.このとき，とり扱い方によっては主要解析 の結果にバイアスをもたらすことが危惧される．他方で欠測が生じる原因は多種多樣であり，す べての症例を同樣に対処することは困難であり，兴の対処の仕方においてもすべての状況で一樣 に適用可能な方策あるいは統計的方法論は提案されていない . ICH-E9 ガイドライン (臨床試験の ための統計的原則）においても，「欠測値は，臨床試験において偏りを起こし得る代表的な原因で ある」としながらも，欠測値の問題については部分的にしか言及されていない．ヨーロッパにお いては, 新薬の審査・承認に携わる European Medicines Agency (EMEA) の組織の一つである Jpn J Biomet Vol. 27, Special Issue, 2006 
Committee for Proprietary Medical Product (CPMP) から，2001 年 11 月に "Point to Consider on Missing Data” (以降, PtC と略す) が公布され, 欠測值のとり扱いに関して考察すべき事項が 列挙されている . 欠測值は臨床試験で観測されるすべての項目で生じ得るが， PtC は ITT の原則 に基づく主要変数の解析を主に想定していると考えられる . 本報告では , この想定の下で PtCの 記載内容を紹介する (第 2 節). 㶢して，いくつかの事項に焦点をあてて問題点を議論する (第 3 節).

\section{PtC の内容}

$\mathrm{PtC}$ は第 1 節「序」, 第 2 節「欠測值がデータ解析と解釈に及ぼす影響」, 第 3 節「欠測值のと り扱い」, 第 4 節「一般的な推奨事項」から構成されている. 臨床試験では光のデザインや主要 変数に応じて種々のタイプの欠測が生じ得るが, PtCでは, 規定された投与期間を満了せずに何 らかの理由て試験から脱落したために, ある時点以降の主要変数が欠測である場面を主に想定し ているようである．他にも，あるイベントが生起するまでの時間を主要変数とする試験で, イベ ントが生起する前に脱落, あるいは, 規定された観察期間内でイベントが生起しない場合は「中 途打ち切り」と呼ばれているが, 弚のとり扱いには殆ど言及されていない．また, 主要解析では ベースラインで観測される項目が共変量として重要になる場合が少なくないが，このような項目 が欠測の場合への対処も殆どとり上げられていない. 钅のため, PtC は主要変数の経時的な観測 において臨床試験からの脱落によって生じる欠測を暗黙裡に想定しているものと解釈する．

\section{1 概 論}

$\mathrm{PtC}$ の第 1 節では，「欠測值は臨床試験のデータを解析するうえでバイアスの潜在的な原因にな る . 欠測値が多ければ, 試験の結果の解釈は常に疑わしいものになる」としている．乥れにもか かわらず，PtCでも指摘しているように，欠測値に関して現行で利用できる規制上のガイダンス が用意されていない. 兴の理由の一つとして, 主要変数の欠測値が生じる理由, あるいは患者が 試験から脱落する理由が多岐に渡るためであると考えられる . 例えば , 脱落の原因の内訳として， 患者か試験の途中で同意を撤回することによる脱落，割付けられた薬阁归が有効であったために来 院の必要なしと患者が判断することによる脱落, 薬剤が無効であった, あるいは副作用が生じた ために薬斉の投与を継続することが困難であることによる脱落 , 患者の転居により通院できなく なったことによる脱落などが考えられる．として，この脱落の理由によって欠測データのとり扱 い方が異なり，適切なとり扱いをしなければ解析結果にバイアスが生じることが危惧される．

$\mathrm{PtC}$ には記載されていないが, 欠測発生のメカニズム (以降 , 欠測メカニズムと呼称する) に言 及しておくことは後述の議論に対して有用である .一般に , 欠測メカニズムは大きく (1) missing completely at random (MCAR), (2) missing at random (MAR), (3) missing not at random (MNAR) の 3 つに分類できる (竹内他, 1996; Little and Rubin, 2002) . MCAR は主要変数（あ るいは主要評価項目) の值とは全く無関係な原因によって欠測が生じることを意味する . MAR は 実際に観測された主要変数の值に依存して欠測が生じる場合に相当する . 例えば血圧を主要変数 とする臨床試験で， ある時点での血圧がある閾値を超えた場合に試験から脱落すると規定してい る場合に , 弚の時点から後の欠測は過去に観測された血圧に依存しているためMAR と見なすこ 
とができる (Murray, 2005) . MNAR は観測されるはずであった主要変数の值に依存して欠測が 生じたことを意味する . 症状の急な悪化により患者か試験から脱落することによる欠測が MNAR の例であると考えられる.欠測あるいは脱落の発生メカニズムを考慮して適切な解析法を選択しな ければバイアスが生じる (Little and Rubin, 2002). 最尤法で推測を行う場合, MCAR と MAR による欠測については，产の発生メカニズムのモデル化は不要であるが， MNAR の場合には発生 メカニズムのモデル化が必要である (Little, 1995). しかしながら，欠測メカニズムを同定し，光 の統計的なエビデンスを示すことは一般に容易ではない (Murray, 2005) . さらに比較臨床試験に おいては脱落の原因が薬剤群間で異なることによって比較可能性が損なわれることが危惧される．

欠測が生じる理由は樣々であり，光の理由や欠測の割合が最終結果に及ぼす影響は試験毎に異 なる．PtCでは，薬斉効果の検定および推定に関して，欠測がどの程度までバイアスを含んだ結 論を導くかは, 多くの因子によって左右される. 光れらには欠測, 薬斉の割付け, 反応変数間の 関係や薬剂効果の指標のタイプが含まれる」と記述されている .

\section{2 欠測值がデータ解析の結果と解釈に及ぼす影響}

$\mathrm{PtC}$ の第 2 節では，欠測値を含む患者をすべて解析から単純に除外することによる問題を (1) 検出力と主要変数の変動, および, $(2)$ バイアスの観点から議論している.

(1) の検出力と主要変数の変動については, 欠測值を含む患者を除外することによって, 群間比 較のための検出力が小さくなることか指摘されている．また， 欠測值が生じた患者は主要変数に 関して極端な值をとりやすいことが危惧される，例えば, 薬阁に効果があり主要変数が極端によ い値をとること，逆に，薬剂が無効であり極端に悪い値をとることによる試験からの脱落は起こ り得る.PtC では, 極端な值を解析から除外することで主要変数の変動を過小推定することの危 惧が指摘されている.

(2) のバイアスについて , PtC では欠測により生じる最も重要な問題であるとし，次の事項へ の影響を指摘している．

i) 薬剂効果の推定

ii）薬剂群間の比較可能性

iii） 標的母集団に対する試験標本の代表性

そして, 薬斉効果の推定においてバイアスが生じるかどうかは, 欠測, 薬斉の割付け, 主要変数 の関係に依存すると記載されている，例として，ある薬剤群での主要変数が他の薬斉群に比して 欠測になりやすいことがあっても, 欠測が主要変数の值と独立であれば, 欠測症例を除外しても 群間比較でのバイアスは生じないであろうと記述されている．また，測が観測されなかった主 要変数の值に関係すれば, 例えば欠測が生じた患者で症状悪化が多ければ，たとえ欠測の割合が 薬斉群間で同じであったとしてもバイアスが生じることが指摘されている．さらに，測が観測 されなかった主要変数の值だけでなく，薬刘にも依存する場合にもバイアスが生じることが指摘 されている．これは欠測が MNAR のメカニズムによって発生している場合に相当するため，慎 重なとり扱いが必要である.

欠測症例を除外した解析がどの程度のバイアスをもたらすかは欠測メカニズムに依存する．し かしながら，一般的に欠測メカニズムを同定することは困難である．炎のため， PtCでは欠測を 
潜在的なバイアスと考えて保守的な方法を用いることか賢明であると記述されている．

\section{3 欠測值のとり扱い}

$\mathrm{PtC}$ の第 3 節では欠測データのとり扱いに関する留意点が言及されている.最初に , 欠測のある 患者を無視して, 観測值か完備している患者のみに基づく解析 , すなわち, complete case analysis は， 2.2 節で検討したように薬斉効果の推定値などにバイアスを与え得ること，ITT の原則に反し ていることから, 主要解析の接近法として一般的には許容されないと記述されている. Complete case analysis は欠測メカニズムが MCAR である場合にのみバイアスを回避できるが, 臨床試験 において MCAR の仮定は現実的には受け入れられない (Murray, 2005) . 一方で, 開発の初期の 段階に実施される探索的試験のデータ解析，あるいは, 検証的試験で結果のロバスト性を示すた めの副次的解析として許容されるケースはありうると記述されている .

次に，側値の補完 (Imputation) について言及されている. 通常，所与の投与期間にわたつ て経時的に患者を追跡する臨床試験では, 主要評価項目についてベースラインから投与期間の最 終時点までの変化量が主要変数として用いられることが少なくない． ITT の原則では脱落して最 終時点の值が欠測である患者も解析対象にするため, 兴のような患者の最終時点の値を補完する ことが必要になる．PtCでは欠測值の補完方法について，すべての状況でゴールドスタンダード と見なせる方法はないとしたうえで, 欠測値の補完方法がいくつか論じられている .

補完方法として，最初に沮上にあがっているのはLOCF (Last Observation Carried Forward) である. $\mathrm{LOCF}$ は脱落前に得られた最後の観測値を, 最終時点を含む脱落後の時点の值として用い るものであり, 臨床試験でかなり広範に適用されている方法である . PtC では, LOCF は変数の 值か時点を通して一定と仮定できる場合に適切になり得ると記述されている．しかしながら，多く の臨床的状況では脱落後に一定の值をとって推移するとは考えにくいため, 多くの状況で LOCF を許容できないと記述されている．乥して，LOCF の妥当性に関わる要因として，脱落の割合と 頻度に関する薬斉群間の差異, 自然な経時変化の方向, 脱落の理由が含まれると指摘されている． LOCF に付随する問題については 3 節で議論する .

他の欠測値の補完法として , 3 節でもとりあげるように, 何通りかの接近法が考えられる (Verbeke and Molenberghs, 1997; Koch, 2004) . 同一患者からの情報 , ベースライン特性か類似した別な患 者からの情報を用いる接近法などが言及されている．ただし，多くの方法は，補完值を推定する にあたって欠測値のもつ不確実性を無視するため，標準誤差を小さく偏らせるリスクを有してい ると指摘されている．乥こで, EM アルゴリズムなど最尤法に基礎をおく方法, および, 多重補 完法 (Multiple Imputation) の適用が示唆されている.しかしながら，これらの方法は欠測メカ ニズムに MAR を仮定しており，MNAR によって脱落する患者が多い場合には一般に適切ではな いとされている (Verbeke and Molenberghs, 1997) .これとは別に, ベースラインと最終時点の みの観測値だけでなく，光の間のすべての観測值も用いた解析が考えられる．線形混合効果モデ ルは光の一つであり，側值が存在するもとでも適用できる方法として言及されている．しかし ながら，欠測メカニズムに MCAR または MAR を仮定していることに注意したい .この線形混 合効果モデルに基づく解析についても 3 節で議論する . 


\section{4 一般的な推奨事項}

$\mathrm{PtC}$ の第 4 節では欠測值の対処方法に対する一般的な推奨事項が述べられている .

第 1 に, 欠測を回避できるデザインを事前に工夫することの重要性が強調されている．また， 臨床試験で発生する欠測値の個数, より具体的には脱落症例数を事前に予想することの有用性が 示唆されている．また，欠測あるいは脱落の生じやすさは, (a) 主要変数の性質, (b) 臨床試験の 期間，(c) 服薬遵守の程度，(d) 治療方法 (薬剂)，に依存すると記述されている.例えば (a)に ついて主要変数が死亡の有無であれば欠測值は生じ難いが, 患者の積極的な参加やより精緻な診 断が必要である場合に欠測の生じやすいことが示唆される．

第 2 に，欠測值の対処方法によって結果が異なることが危惧されるため，実施計画書の統計解 析の項で対処方法を予め定めることが重要であり，方法の詳細とともに，关れが適切と考えられ る理由を含め，正当化が必要であることが強調されている．さらに，侧値の個数を予見し，光 れがどの程度までならは許容できるかを見積もっておくことか推奨されている．この理由として， 第一に关の結果が必要症例数の計算に影響を与え得ること，第二に補完の信頼性が欠測值の増加 とともに疑問視されることが挙げられている．他方で，側あるいは脱落に関しては過去の臨床 試験の成績が光のまま反映されるとは限らず，十分予測できないこともあり得る，光のため，側 值に対処するための戦略あるいは方法を盲検化レビュー時で変更する余地を残し，このことを実 施計画書で言及しておくことか望ましいと記述されている．また，できるだけ保守的な方法を選 択すること，試験薬に有利にならないような方法を選択することの重要性が記述されている．優 越性試験では保守的な方法をとることが好ましいが，非劣性試験ではそのような方法が薬斉間の 差異を過小推定することが危惧される . 弚の点も考慮して , 臨床試験の目的に応じて薬剤間差を 過大あるいは過小推定しないことか望ましいと記述されている．

第 3 に，欠測値が生じる割合や時点に関して群間比較をしておくことが推奨されている．

第 4 に，側值の対処に関して広く受容できる手順や接近法がないため，解析結果のロバス卜 性を示すための感度分析が推奨されている . PtC では, 感度分析の例として以下の手順が示され ている．

・両方の薬剂群のすべての欠測値に尤も光れらしい值を補完する解析と両方の投与群のすべての 欠測値に考えられる最悪の值を補完する解析の結果を比較すること

・対照群の欠測值にとり得る最良の值を補完し, 試験薬群の欠測值にとり得る最悪の值を補完す る解析，およびその逆の解析の結果を比較すること

・フルセットを対象にした解析と complete case analysis の結果を比較すること 感度分析の結果が一貫性をもち，概ね類似した薬斉効果の推定值が得られていれば， 欠測あるい は脱落が全体の結論に殁ど影響を与えていないという確信を得ることができる．逆に一貫性のな い結果が得られた場合には欠測あるいは脱落か試験の結論に及ぼす影響を議論することが必要で あり，場合によっては試験の妥当性が疑問視されることもあると記述されている．

第 5 に，PtCでは，最終報告書には事前に計画された欠測値の対処方法や炎の計画の修正は統 計解析の項に含めるべきであり，欠測値の個数，時期 , パターン , 有効性と安全性評価における 影響に関する議論を報告書に記載すべきであることが記述されている．また，補完に用いた值が 
同定できるように光のリストを作成することが必要であると記述されている．

\section{3. 欠測値の対処に付随する問題点}

$\mathrm{PtC}$ の第 2 節で指摘されているように，欠測値のある患者を除外した complete case analysis がバイアスをもたらし得ることは周知のこととして受け入れ可能であると思われる．もとより比 較臨床試験の主要解析においては ITT の原則に従うことが ICH E9 ガイドラインで規定されてい るため, 欠測値を含む患者を主要解析から安易に除外することはこの原則に反する．より現実的 な問題は欠測值を含む患者のとり扱いおよび欠測値への対処である $\mathrm{PtC}$ が指摘しているように， 欠測值の対処に関して広く受け入れられた接近法は存在しないため, 主要変数の性質, 薬剂, 欠 測の時点と原因を総合的に勘案し, 薬斉間差についてバイアスができるだけ小さくなるような対 処法を選定することが必要になる．この節では欠測值の対処法について，1) LOCF ，2) 欠測值の 補完方法，3) 欠測值を意識しないモデルに基づく解析方法，4）側メカニズムを考慮に入れた解 析方法, の 4 つの手法について議論する .

\subsection{LOCF の適切性}

LOCF は光の適用が容易でわかりやすいことから幅広く適用されている方法である . 他方で光 の胡散臭さも完全に拭いさることはできずに適用しているのか現状であると考えられる .ここで は LOCF の適切性について検討する . 炎の検討にあたって , 主要評価項目が経時的に観測されて いるが , 投与期間の最終時点のみの観測值に注目し , ベースラインからの変化量を評価すること を考える. 光して, 試験から患者が中途で脱落したために最終時点の欠測値をLOCFにより直近 の観測值で補完する状況を考える . 変化量に基づく解析は臨床家にも解釈が容易であり，解析方 法も分散分析といった標準的な方法を適用できるため, 実際の臨床試験でよく適用されていると 思われる .

Demitras (2005) では，LOCF はFDA に申請する臨床試験の解析でよく適用されている，と 記述されている．弚の理由としては, 評価項目が時点とともに単調な増加あるいは減少すること が薬斉の効果として現れると仮定する場合に，脱落により欠測が生じた時点より以前の観測值を 補完することで薬斉効果が小さく評価され，薬斉間差が保守的に評価される傾向にあることが考 えられる . 兴のような保守的な結果は規制上では受け入れられやすいと思われる.しかしながら， 主要変数あるいは主要評価項目の特徵と脱落のタイミングを無視して安易な LOCF を行うことは バイアスの原因になる例を以下に示す．

ある進行性の疾患の進行を遅らせることか薬悄の効果であり，ある評価項目の最終時点におけ るベースラインからの変化量を試験薬とプラセボで比較する臨床試験を考える . この場合, 評価 項目のベースラインが患者における最良值であり, 疾患が進行するほどベースラインからの変化 量が大きくなるものとし，ベースラインからの変化を抑制することが薬剤の効果と見なされる． このような状況でLOCF を適用すれば, 早期に脱落した患者ほど変化量は小さく評価されてバイ アスをもつことになる (図 1 の上図を参照) . そして, 病態の悪化によりプラセボ群で早期に脱落 する患者の割合が試験薬群に比してかなり大きければ, 全体的にプラセボ群での変化量が小さく なり，プラセボ群に有利なバイアスが働くことになる．逆に，試験薬群で副作用発現により早期 


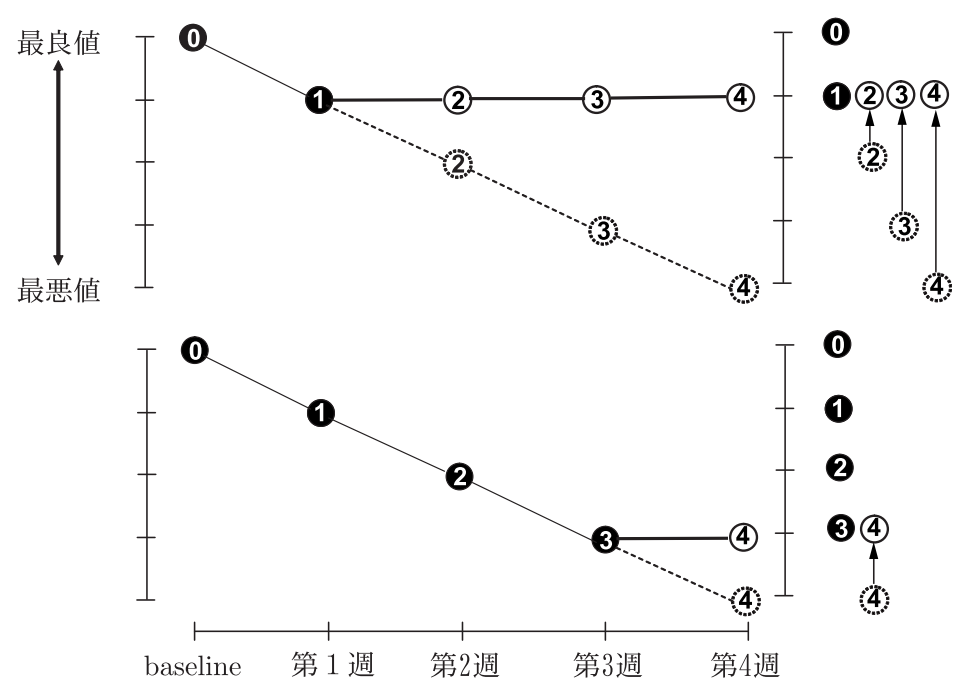

図 1. 進行性疾患の臨床試験における LOCF の例 . 上図は早期脱落により欠測が発生した例，下

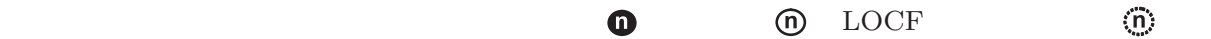
測を示す.[竹内・田崎 (2005) からの転載]

の段階で脱落する患者の割合がプラセボ群に比して高く , プラセボ群で他の理由による脱落する 患者が少なければ，LOCF によって試験薬群の変化量は小さくなり，試験薬に有利なバイアスが 働く．前者の場合には LOCF によって薬斉間差が保守的に評価されるため，規制上光のようなバ イアスは受け入れ可能かもしれないが，スポンサーにとっては重要な問題である．なお，臨床試 験の後期に脱落する患者が多い場合には关のようなバイアスは小さくなるものと考えられる (図 1 の下図を参照) .

他方，抗うつ薬の臨床試験のように，プラセボ効果が大きく病態が悪化することが見られずに， 殁どの患者で評価項目がベースラインから単調に増加あるいは減少すると期待される状況を考え る .この状況ではベースラインが最悪值であり, ベースラインからの変化量が大きくなることが 薬斉効果と見なされる .このとき，試験薬群で副作用により早期に脱落する患者の割合がプラセ ボ群に比して高ければ, LOCF によって試験薬群の変化量は小さくなり，プラセボ群に有利なバ イアスが働く．この場合も薬斉間差が保守的になると考えられる．保守的傾向は優越性試験であ れば規制上は問題にならないであろうが , 非劣性試験では試験薬と実薬対照群との差異を小さく してしまうため問題になり得るであろう．プラセボ群，試験薬群，実薬対照群を用いた 3 アーム 試験では，LOCF を適用する際には十分に注意することが必要である．

LOCF に付随する問題点として , Fizmaurice et al. (2004) と Demirtas (2005) は標準誤差を過 小推定する傾向にあり，実際には保守的にはなっていないことを指摘している. Mallinckrodt et al. (2001a, b) は精神科領域の臨床試験に類似した状況を想定した下でシミュレーションを実施し， 最終時点における薬斉間比較の標準誤差を LOCF を用いた通常の $\mathrm{t}$ 検定に基づく 2 群比較と線形 混合効果モデルの下での対比に基づく 2 群比較との間で評価している. 兴の結果において, 前者の 
標準誤差が後者に比して過小推定されていること，また前者の第 1 種の過誤が後者に比して大き い傾向にあることを示している . Mallinckrodt et al. (2001a, b) のシミュレーションによる評価も 限定的であり，すべての状況にあてはまるとは限らないかもしれない．しかしながら，LOCF を 適用する際には欠測の時期および割合が標隼誤差に及ぼす影響も考慮することが必要であり，と くに欠測値の割合か薬剤群間で異なる場合にはかなりの注意を要する．

\section{2 欠測值の補完法}

前節の LOCF 法も欠測值を補完する方法の一つであるが， 欠測値の補完法として同一患者から の情報に基づく接近法から既存対照のデータベースを用いた接近法など種々の方法が提案されて いる (Verbeke and Molenberghs, 1997; Little and Rubin, 2002; 岩崎, 2002; Koch, 2004) . PtC では, 2.3 節で示したように, 欠測值を補完する方法の多くは補完値を推定する際に光の不確定 性を無視するため，標隼誤差を下方に推定するリスクを有していると記述されている．前節のよ うにLOCF 法の標準誤差が過小推定されがちであることも標本変動による不確定性を無視してい ることが一つの原因であると考えられる .さらに , Verbeke and Molenberghs (1997) では, 殆ど すべての補完方法に対して，(1) 補完方法による結果を完全に信頼できない，すなわち，うまく いった状況と光うでない状況を区別することが難しい，(2) 欠測補完は満足のいく点推定值を得 るために後付けの補正をすることが多い，(3) 単純で精度の高い推定量を与えることができない， といった限界か指摘されている．多くの方法で欠測メカニズムに MCAR あるいは MAR が仮定 されているため (岩崎, 2002), 薬剤が無効で病態が悪化して脱落した患者の欠測值を単純に補完 することはバイアスをもたらすと考えられる .

上記の議論から, 欠測值を補完する解析を行う場合には, 単一の方法のみを適用するだけでは 不十分であることは明らかであり，主要解析では数通りの方法を適用することによって感度分析 を行い , 結果のロバスト性を確かめることが必要である . Koch (2004) は感度分析として以下の 手順を提案している.

1) 欠測値を直近の先行観測值で補完する (LOCF)

2) 欠測値を考えられる最悪の值で補完する (最悪值)

3) 欠測値を考えられる最良の值で補完する (最良値)

4) 欠測値は欠測のままとし，実際に得られている観測値だけで解析する (実観測値)

5) 欠測値を「尤もらしい統計モデル」で求めた推定值で補完する (モデル)

6) 対照群の欠測值を最良值, 被験薬群の欠測值を最悪值で補完する (保守的) .

Koch (2004) はこれらの方法を適用することで一貫した結果が得られることか望ましいと述べて いる．しかしながら，欠測值の割合が高い，あるいは，明確な薬阂間差がない場合には，一貫し た結果を得ることは難しいと述べている．

上述のように，観測值や平均值で補完するといった単純な補完法は標本変動による不確定性を 考慮していないという問題がある .これに対し，複数個の値を補完することで不確定性を考慮す る多重補完法が提案されている (Rubin, 1987; Schafer, 1997; 岩崎, 2002) . PtCでも標準誤差を 過小推定するリスクが小さい方法として多重補完法の適用が示唆されている.多重補完法は Bayes 理論を背景としたシミュレーションに基づく方法であり，統計モデルに基づいて欠測値を補完し 
た完全なデータセットを所与の個数だけ生成するステップ，各データセットに統計的方法を適用 するステップ, 兴の適用結果を併合するステップの 3 つのステップで構成される (Verbeke and Molenberghs, 1997; 阿部他, 2005) .ただし , データセットを生成するステップでは欠測值を補完 する方法を与える必要があり，Regression 法をはじめとして種々の接近法あるいはモデルが提案 されている (阿部他, 2005) . 実際の適用にあたっては , 選択した欠測值の補完モデルが適切であ るか, 他のモデルを仮定した場合に一貫した結果が得られるか，などを点検しておくことが必要 であろう . SAS の MI プロシジャやSOLAS（渡辺・山口, 2000) といった多重補完法のソフトウェ アも整備されてきたため, 実際の臨床試験での適用経験が積まれることを期待したい . なお , 多 重補完法は欠測メカニズムに MAR を想定していることに注意したい .

\section{3 欠測值を意識しないモデルに基づく解析方法}

欠測値の対処方法において , 欠測値の補完の問題に議論が集中しがちになるのは, 3.1 節のよう に, 経時的に観測される主要評価項目の最終時点の観測値のみに基づいた主要変数が用いられる ことが考えられる.このような主要変数が用いられる理由として, 変化量に基づいた薬斉間比較 の仮説が明確であること，標準的な統計解析法を適用できること，弚の適用結果が臨床的にも解 釈しやすいことが考えられる.他方，最終時点だけでなく，ベースラインから最終時点までの経時 推移に基づいて薬斉間比較を行うことが考えられる．この経時推移に基づく薬斉間比較を行うた めの統計モデルとして , 線形混合効果モデルを適用できる .この解析では, 脱落した患者も含め て利用可能なデータをすべて用いることができる . 欠測メカニズムが MAR の下で尤度に基づく 推測を行うとき, 線形混合効果モデルに基づく解析では欠測メカニズムのモデル化が不要であり， 結果として欠測值を意識せずに解析することが可能である (Verbeke and Molenberghs, 1997) . 経時推移に基づく薬斉間比較で利用される線形混合効果モデルとしては, 薬斉効果, 時点効果, 薬剂 $\times$ 時間交互作用を含む分散分析型モデルから経時変化のトレンドを回帰式で表現した回帰型 モデルが考えられる . 回帰型モデルでは , 例えば時間と主要評価項目との間に切片と傾きからな る 1 次の回帰式を想定し，傾きに基づいて薬阁間比較が行われる. SAS の Mixed プロシジャなど ソフトウェアの整備によって分散分析型モデルと回帰型モデルの両方をあてはめることが可能に なっている．

他方 , 線形混合効果モデルに基づく解析には，解析結果を臨床的に解釈しにくい場合があるこ と，非劣性試験において非劣性マージンを考慮した解析の方法論か確立されていないこと，あて はめたモデルの妥当性を診断することが必要であること， 欠測メカニズムが MNAR の場合には バイアスをもたらし得ること，などの難点がある．

3.1 節で言及した Mallinckrodt et al. (2001a, b) と Molenberghs et al. (2004) は線形混合効果モ デルの下で最終時点の解析を行う手順を提案している．乥こでは，経時的に観測されるべースラ インからの変化量に対して分散分析型の線形混合効果モデルをあてはめ, 最終時点での薬斉間比 較を行うために，薬剂 $\times$ 時点交互作用の変動に含まれる，最終時点における薬斉間の対比成分が 評価されている. Mallinckrodt et al. (2001a, b) では, 最終時点における変化量の薬斉間差の推定 值のバイアスと 2 薬斉間比較の標準誤差について LOCF と線形混合効果モデルとの間で比較した 結果 , バイアスと標準誤差の両方で後者が前者に比して総じて良好であったことが報告されてい 
る .この結果から, 主要評価項目が経時的に観測される臨床試験では, LOCF を用いた最終時点 に基づく解析を主要解析にすることは推奨できないとしている .

Mallinckrodt et al. (2001a, b) の手順は, 欠測值の補完を回避できること, 最終時点での比較が 主体ながら経時推移を考慮していること, 経時推移に基づく評価で遭遇しがちな臨床的な解釈上 の難点を回避できること, 非劣性試験でも適用可能であることから, 主要解析として適用できる 方法であると考えられる．

\section{4 欠測メカニズムが MNAR の場合の解析方法}

上記で論じた欠測値の補完方法およびモデルに基づく方法では, 欠測メカニズムが MCAR あ るいは MAR であることが仮定されている . 兴のため，これらの方法を適用する際にはこの仮定 の妥当性を確かめてから利用することか望ましい．しかしながら，次測メカニズムが MNAR で あるか否かを検定する方法は確立されていない (竹内他, 1996; Verbeke and Molenberghs, 1997) . 実際の臨床試験ではすべての欠測值に MCAR あるいはMAR を仮定することは難しいと考えら れるが, PtCではこの仮定が妥当でない場合の対処方法については殆ど言及されていない，弚の 理由として, 実際の臨床試験の状況を適切に反映した , 欠測メカニズムを考慮に入れた方法が提 案されているものの, 実際の臨床試験に適用できるほど十分に整備されていないことが考えられ る . 欠測メカニズムに MNAR を想定した方法として Selection モデルと Pattern Mixture モデル が提案されている (Little, 1995) . 前者は主要変数 (応答) を与えたもとで欠測メカニズムをモ デル化するが , 後者は欠測パターン別に応答の分布をモデル化し，応答の周辺分布を異なる欠測 パターンからなる混合分布として表現する . Pattern Mixture モデルは , Selection モデルと異な り，欠測メカニズムに関する明示的な規定を必要としないという利点をもつ . 臨床試験において Pattern Mixture モデルの適用が主に検討されているのは (例えば， Hedeker and Gibbons, 1997; Siddiqui and Ali, 1998), Selection モデルに比べて欠測メカニズムのモデルの仮定が緩やかであ るためと考えられる . 現状では, Pattern Mixture モデルの性能が十分明らかでないこと，および ソフトウェアの整備が不十分であることを考慮すると, Pattern Mixture モデルを主要解析で用 いることの適切性を主張することは難しいと思われる．しかしながら，主要解析に対する感度分 析として产の適用を検討する価値はあると考える。実際に，FDAで公開されている，新薬審査報 告書の Statistical Review Report において, 経時的に観測される項目の欠測值のとり扱いが言及 されている品目がある．乥こでは欠測值の対処方法の適切性および光の適用結果のロバスト性を 示すために Pattern Mixture モデルの適用が示唆されている (FDA, 1998, 1999).

\section{4. 結びに代えて}

本稿では, CPMP から公布された Point to Consider on Missing Data の記述内容を紹介し，と

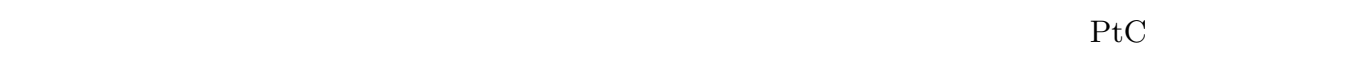
ているように, 欠測値をとり扱うための一本道の方法は存在しない . そのため, 主要解析におい て欠測值をとり扱う方法を事前に定義し, 弚の適切性を明記するとともに, 弚の結果のロバスト 性を確認するための感度分析の方法も併せて規定しておくことが必要である. 光して, 最終報告 書あるいは別添の文書において, 実際に行った解析内容および結果を詳細に記述することが重要 
になるであろう .

他方，欠測值に対処するためにどのような方法を用いても，欠測あるいは脱落した患者の割合 が高ければ，臨床試験への信頼性が乏しくなることは明らかである．PtCでも言及されているよ うに，側値を回避できるデザインを計画時に工夫をすることにも積極的にとり組まなければな らない，元のためには, 前相までの臨床試験あるいは類薬の臨床試験の成績に基づいて, 脱落が 生じた時期，理由，頻度，パターンを吟味して欠測が臨床試験の成績に及ぼした影響を評価する ことが必要であろう，光して，光の結果を試験の計画時において投与期間の変更あるいは主要評 価項目の見直しといった形でデザインに反映させることが重要である .

\section{参考文献}

Demirtas, H. (2005). Bayesian analyisis of hierarchical pattern-mixture models for clinical trials data with attrition and comparisons to commonly used ad-hoc and model-based approaches. Journal of Biopharmaceutical Statistics, 15, 383-402.

FDA (1998). Statistical Review(s): NDA 20-896

(http://www.fda.gov/cder/foi/nda/98/20896-stat.pdf).

FDA (1999). Statistical Review(s): NDA 50-778

(http://www.fda.gov/cder/foi/nda/99/50-778_Ellence_statr.pdf).

Fitzmaurice, G. M., Laird, N. M. and Ware, J. H. (2004). Applied Longitudinal Analysis. John Wiley \& Sons.

Koch, G. (2004). Strategic use of biostatistics in biopharmaceutical development. Manuscript for the seminar held at American Club in Japan (August 28, 2004).

Hedeker, D. and Gibbons, R. D. (1997). Application of random-effects pattern-mixture models for missing data in londitudinal studies. Psychological Methods, 2, 66-78.

Little, R. J. A. and Rubin, D. B. (2002). Statistical Analysis with Missing Data (2 ${ }^{\text {nd }}$ edition), John Wiley \& Sons.

Little, R. J. A. (1995). Modelling the drop-out mechanism in repeated measures studies. Journal of the American Statistical Association, 90, 1112-1121.

Mallinckrodt, C. H., Clark, W. S. and David, S. R. (2001a). Accounting for dropout bias using mixed-effects models. Journal of Biopharmaceutical Statistics, 11, 9-21.

Mallinckrodt, C. H., Clark, W. S. and David, S. R. (2001b). Type I error rates from mixed effects model repeated measures versus fixed effects ANOVA with missing values imputed via last observation carried forward. Drug Information Journal, 35, 1215-1225.

Molenberghs, G., Thijs, H. Jansen, I., Beunkens, C., Kenward, M. G., Mallinckrodt, C. and Carroll, R. J. (2004). Analyzing Incomplete Longitudinal Clinical Trial Data. Biostatistics. 7, 445-464.

Murray, G. D. (2005). Missing data in Clinical trials. Encyclopedia of Biostatistics (2 ${ }^{\text {nd }}$ edition) ed. by Armitage, P. and Colton,T., Vol.5, 3288-3291, John Wiley \& Sons. 
Schafer, J. L. (1997). Analysis of Incomplete Multivariate Data. Chapman \& Hall.

Siddiqui, O. and Ali, M. A. (1998). A comparison of the random-effects pattern mixture model with last- observation-carried-forward (LOCF) analysis in longitudinal clinical trials with dropouts. Journal of Biopharmaceutical Statistics, 8, 545-563.

Verbeke, G. and Molenberghs, G. (1997). Linear Mixed Models in Practice : A SAS Oriented Approach. Springer-Verlag [松山裕・山口拓洋編訳 (2001) . 医学統計のための線形混合効果 モデル : SAS によるアプローチ . サイエンティスト社] .

Verbeke, G., Lesaffre, E. and Spiessens, B. (2001). The practical use of different strategies to handle dropout in longitudinal studies. Drug Information Journal, 35, 419-434.

阿部貴行・稲葉由之・岩崎 学 (2005). 不完全データに対するソフトウェアの比較 . 日本計算機統 計学会第 19 回大会論文集, 97-100.

岩崎 学 (2002). 不完全データの解析 . エコノミスト社.

竹内雅子・田崎武信 (2005) . LOCF (欠測補完) による比較バイアス . 解析センターを知っていた だくキャンペーン用リーフレット．

竹内正弘・Hung, H. M. J. ・ Ware, J. H.・Laird, N .M. (1996). 経時観察データの統計解析法, 薬 理と治療，24, 1955-1969.

渡辺美智子・山口和範 (2000) . EM アルゴリズムと不完全データの諸問題 . 多賀出版 . 